\title{
Political Law of Advocate Arrangements in Indonesia
}

\author{
Dr. Erry Meta, S.H., M.H. \\ Dr. Soetomo University
}

\begin{abstract}
Indonesia as a state law should put an effort in enforcing justice based on the law for society's interest, upholding the rule of law and human rights. One of the efforts is through the development of law related to advocating arrangements. The existence of Advocate Law is to create a constitutional state law and judicious law enforcement so that every person is viewed equally before the law, to get access to justice. In the context of Political Law in democratic Indonesia, it is known that the arrangements of law related to advocate are aimed at the legal responsive character.
\end{abstract}

Keywords: Advocate, Political Law, Responsive

DOI: $10.7176 / \mathrm{JLPG} / 118-08$

Publication date: February $28^{\text {th }} 2022$

\section{Introduction}

Due to the importance of the Advocate's role and function, the status of the advocate as a profession must be free, independent, and responsible and must be equalized to the judiciary and other law enforcement agencies namely police, prosecutor, and court as a concept of Four Houses of Law Enforcement Officials. Based on the DutchIndonesia Legal Dictionary, the definition of Advocate or Advocaat or Advocaat En Proccureur is Legal Advisor; Advocate; Case Defender. ${ }^{1}$ Whereas, in Latin-Indonesia Dictionary, advocate means a person whose job is to help someone's case, mitigating witness. ${ }^{2}$ In Black's Law Dictionary, advocate means "one who assists, defends or pleads for another. One who renders legal advice and aid and pleads the cause of another before a court or a tribunal. A person learned in the law and duly admitted to practice, who assists his client with advice, and pleads for him in open court. An assistant, adviser; plead for causes." 3 Whereas in English Language Dictionary, the advocate is defined as "An advocate is a lawyer who speaks in favor of someone or defends them in a court of law."4

In reality, the existence of an Advocate is not only legal work but more to a legal profession, it can be seen in Article 1 number (1) Constitution Number 18 the Year 2003 on Advocate ("Advocate Law"), stated: "An advocate is a person whose profession is to provide legal service, inside and outside court that fulfilled the requirements based on this Constitution". Normatively, since the enactment of Advocate Law, it has been decided and known that advocate is a legal profession that does work inside and outside the court.

Besides that, the Advocate Code of Ethics explains the definition of an advocate in Article 1 letter (a), which stated: "An advocate is a person whose provides legal service, both inside and outside the court that complies with the requirements according to the valid Constitution, either an advocate, lawyer, legal advisor, attorney, or as a legal consultant."

Based on the function, principally the services that are provided by an advocate can be divided into three categories as follows:

1. Verbal and written advice towards client's cases, including assistance in formulating various kinds of legal documents. In this category, the advocate interprets legal documents related to Indonesia or international laws and regulations accurately;

2. Assisting in negotiations or mediation. In this case, an advocate should understand the client's desire as well as the opponent's, the main task is to achieve a satisfying settlement for each party. Sometimes, an advocate is asked to assess evidence which is submitted by the parties, however, the main purpose is the settlement out of court;

3. Assisting client in the court either in civil law, criminal law, administrative law, or Constitutional Court. In a criminal case, the assistance can be started when the client is being investigated by the Police and Prosecutor. ${ }^{5}$

Moreover, historically the arrangements of advocates have been around since before Indonesia's independence. The existing arrangements cannot be separated from the relevant political law both before Indonesia's independence and after Indonesia's independence. On that score, it is an interesting study if the

${ }^{1}$ Yan Pramadya Puspa, Law Dictionary, Aneka, Semarang 1977, pg. 38.

${ }^{2}$ K. Prent C.M., J. Adisubrata, \& W.J.S. Poerwadarminta, Latin-Indonesia Dictionary Kanisius, Yogyakarta, 1969, pg. 2.

${ }^{3}$ Henry Campbel Black, Black's Law Dictionary. St. Paul, MN: West Publishing Co., 1990, pg. 55.

${ }^{4}$ Jhon Sinclair, Collins Cobuild, English Language Dictionary. William Collins Sons \& Co., Ltd., London. 1987, pg. 22.

${ }^{5}$ Mardjono Reksodiputro, "Organization of Advocate Indonesia: Quo Vadis?," JENTERA Law Journal, Edition 19, Year V, (April - June 2009), pg.10. 
arrangements, concerned with the existence of the Advocate, are observed from the Political Law perspective. According to this, advocate arrangements before and after Indonesia's independence will be observed, and then the Political Law of Advocate Arrangements in Indonesia will be discussed in this article.

\section{Discussion}

\subsection{Advocate Arrangements Before Independence}

During the Dutch colonial era, the birth of the advocate profession was not based on the community's need for law, but it was more because of the desire of several Indonesians who happened to have the opportunity to attend legal education. The advocate profession, at that time, was an audacious choice for Indonesians in culture and feudalistic mindset of society that placed civil servants as a noble job compared to an advocate. ${ }^{1}$

Considering the history, getting the profession of advocate among natives was not easy since the requirements were very difficult. Besides that, only those from noble families could have legal education and continue to be an advocate. The regulations that arrange the issue of an advocate in pre-independence are as follows:

a. Staatblad Year 1847 Number 23 and Staatblad Year 1848 Number 57 about Reglement op de rechtelijk organisatie en het beleid de justitie in Indonesie or known as RO, on Article 185 to 192 which arranges "advocaten en procureurs" that is legal advisor who holds law degree.

b. Staatblad Year 1847 Number 40 about Reglement op de Rechtsvordering (RV), in judicature specifically for European (Raad van Justitie) stipulates that each party should be represented by an advocate or procureur.

c. The coronation of King dated 4 May 1926 Number 251 jo. 486 about The Regulation of How to Carry Out, on Chapter, I Part II Article 3 paragraph 3 stipulates that the person who is punished and the person who should provide legal assistance for him before inceptive investigation.

d. Staatblad Year 1926 Number 487 about The Supervision of Person who Provide Legal Assistance, stipulates the supervisory of people who provide legal assistance or people who are authorized to appoint institution and people who can be ordered to assist.

e. Staatblad Year 1927 Number 496 regulates legal advisor which is known as "zaakwaarnemers" or at that time is called "pokrol".

f. Staatblad Year 1941 Number 44 about Herziene Inlandsch Reglement (HIR), in Article 83 h paragraph 6 stipulates that if someone is accused of committing a crime and can be sentenced with the death penalty, the magistrate will ask him whether he wanted to be assisted in the court by a legal advisor. In addition, Article 254 paragraph (1) stipulates that in the trial every accused person has the right to be assisted by a defender to defend himself.

g. Staatblad Year 1944 Number 44 about Het Herziene Inlandsch Reglement or RIB (Updated Indonesian Regulations), in Article 123 stipulates that:

- If agreed, both parties can be assisted or represented by the attorney, who is authorized to do it with a special letter of authority, unless the person who gives authority is present. The plaintiff can also give the authority in the signed letter of request and submitted according to the first paragraph of Article 118 or if the lawsuit is done verbally based on Article 120, so in the final case, this matter must be stated in the note of lawsuit letter.

- Employees who, due to general rules, carry out cases for Indonesia as ambassadors, do not need a special letter of authority.

- District Court has the power to give an order, so both parties, which are represented by their attorneys at the trial, come by themselves. That power does not apply to the President.

The regulations arrangement to be an advocate is stipulated in the R.O (Reglement op de Rechterlijke Organisatie en het Beleid der Justitie), where an advocate together with procureur must be appointed by the Governor General who has fulfilled these requirements:

1. Dutch East Indies Citizen.

2. Bachelor of Law (Doctor or Meester in de Rechten),

3. Passed the exam of civil law, criminal law, commercial law, and constitutional law, and,

4. Had completed an apprenticeship for 3 (three) years.

The requirements above were not easy to obtain by the natives at that time, so if there was a native who held a bachelor's degree and could attend further education to be an advocate, which was very rare, has made the advocate profession special in the society.

The arrangements in carrying out the duties of advocate profession in practice in the court, generally have been regulated in the stipulation: Regeling van de Bijstand en de Vertegenwoordiging van Partijen in Buurgerlijke Zaken voor de Landraden (St. 1927 Nr. 496) on Article 1 paragraph (1) on its principal is stated: "Every person in charge of assisting or representing the parties in civil litigation before the Landraad trial as the

${ }^{1}$ https://radarcom.id/2019/08/13/history-of-association-advocaten-indonesia-pai/ downloaded on 25 August 2020. at 10.07 wib. 
attorney of each party"1.

Arrangements in the ordinance of assistance and representation for the parties in civil litigation before the Landraad trial, both for advocate and procureur, and even each authorized person with the requirements to provide assistance and representation is stipulated in Article 1 paragraph 2: "In the affair of assistance and representation, in any way and under any pretext, it cannot be charged or cannot receive any payment, but by regarding the requirements of this ordinance."2.

Historically, the role of providing legal service by advocate in Indonesia is essential since the Dutch colonial era. Where, as colonial, the formal legal system applied in Indonesia, some of them were adopting a legal system that was stipulated by the Dutch East Indies government. Meanwhile, Indonesian society previously had a set of a traditional legal stipulation that was relatively developed and became the standard in building social systems, arranging social interaction, including solving cases or lawsuits which appeared in the social system and interaction. ${ }^{3}$

The intersection between the foreign legal instruments that were introduced and enforced by Dutch with the existing values in the society, informal relation between the traditional and colonial legal order. One of the links between the two legal worlds was zaakwaarnemer in the villages and professional lawyer (advocaat en procureurs) who was born in big cities, in colonial administrative service, in the government's judiciary, and in law schools. ${ }^{4}$

At first, the function of zaakwaarnemer and professional advocate was essentially not too different, that is to connect societies' legal needs which by Dutch East Indies government required to follow the procedure, mechanism, and working procedure of government's judiciary to fulfill formal legality standards that had been set. The only thing to be distinguished is the prerequisite that must be possessed by both to run the function, and which community is the target of their service, which in turn determined from which community they come from. ${ }^{5}$

The application of Dutch East Indies rules based on the concordance principle and with the King's decree on 16 May 1848 Number 1 (Ordonantie Met Koninklijke Machtiging) as contained in Staatblaad 1848 Number 161 stated that: "Each new rule and regulation to be applied in Netherlands would be applied in Indonesia as well ${ }^{6}$, including Staatblaad 1847-23 juncto Staatsblaad 1848-57, on the Structure of Judicature and Wisdom of Justice (Reglement op de Rechterlijke Organisatie en het Beleid der Justitie) that is abbreviated as R.O."

$R . O$. is the first law regulation that arranged advocate institutions in Indonesia. However, due to political discrimination (dualism) which influenced the application of law in Dutch East Indies, R.O. was applied to Dutch citizens who graduated from universities in Netherland majoring Law or graduated from Law University in Jakarta. R.O. stipulation was applied only to advocaat en procureur who handled cases involving European in the court of Raad van Justitie. Whereas, the regulations for zaakwaarnemer which appeared in native society, were separated arranged afterward in Staatsblaad 1927-496 about The Regulation of Assistance and Representation of the Parties in Civil Suit in the Regence Court. ${ }^{7}$

In the R.O. regulations, an advocate is required to be Meester in de Rechten (Bachelor in Law) and supervised by the Judge of Raad van Justitie with 2 (two) additional proposed advocates. While the position of zaakwaarnemer could represent and defend civil cases in the court of Landraad according to Staatsblaad 1927496 could be filled by anyone, didn't need to be a bachelor of Law, and was supervised fully by the courts. ${ }^{8}$

Due to this political discrimination, the Dutch East Indies government had been determined the allocation of law for Europeans on one side, and natives on the other side. This differentiation was also concerned with the division of judicature institutes that were in charge of the trial between the two parties. Judicature of Resident Iegerecht (District Court), Raad van Justitie (Appelate Court), and Hogerechtschof (Supreme Court) were for Europeans or analogous people. While Judicature of Districtsgerecht, Regenstchaps-gerecht, and Landraad was for natives or analogous people, without regulating the opportunity of appeal for legal cases which appeared between them. ${ }^{9}$

Based on these two different conditions, the implication towards advocate existence in each judicature system was seen clearly. The advocate profession could grow and develop for advocates from the Netherland who were in a session of Europe Court. Meanwhile, in native courts, the role of an advocate in assisting the defendants was insignificant, the existence of the advocate profession was neglected as it was not important

\footnotetext{
${ }^{1}$ Lasdin Wlas, The Horizon of Indonesian Advocates. Liberty. Yogjakarta. 1989. pg. 32.

${ }^{2}$ Ibid. pg.33.

${ }^{3}$ Viswandro, Maria Matilda,\& Bayu Saputra, Knowing Law Enforcement Profession; Carier in Law Reference Book, Medpress Digital, Yogyakarta, 2015. pg.305.

${ }^{4}$ Ibid.

${ }^{5}$ Ibid.

${ }^{6}$ Ibid.pg. 105

${ }^{7}$ Ibid.

${ }^{8}$ Ibid.

${ }^{9}$ Sunarto. Active Role of Judges in Civil Suit. Prenadamedia. Jakarta. 2014. pg. 11.
} 
which then, could not be developed fairly.

\subsection{The Regulation of Advocate After Independence}

After independence, the regulation of advocate is still spreading in several rules and regulations, as in Constitution Number 1 the Year 1950 about The Structure and Power of Indonesia Supreme Court, which acknowledges the right of cassation petitioners to get legal assistance. This matter is stipulated in Article 113 and Article 122, which stated that:

Article 113

(1) Application for cassation examination must be submitted in a letter or verbally by the petitioner or his/her representative, who is intentionally authorized to apply to the registrar in the court of the judge who makes a decision, determination, or action, which requested a cassation examination, which is in Java and Madura within three weeks and outside Java and Madura within six weeks after verdict which already has final power and notified to the petitioner.

(2) The application by the registrar was written in a statement letter and is signed by the registrar and if it is possible also by the petitioner or his/her representative, which statement letter must be attached on case inspection letters and recorded in the list.

(3) The request must be noticed immediately by the opponent by the regristrar. Article 122

(1) Request for cassation inspection must be delivered in a letter or verbally by the petitioner or his/her representative, which is intentionally authorized to submit the request to the Court Registrar or the Judge who decides the verdict, decree, or act requesting for cassation inspection, which is in Java and Madura is within three weeks and outside Java and Madura are within six weeks after the verdict, which the power has already informed to the defendant.

(2) The request by the registrar is written in a statement letter which is signed by the registrar and if possible, also by the petitioner or his/her representative, and on this statement letter, the letters of case inspection must be included and noted in the list.

Furthermore, in 1965, Constitution Number 1 the Year 1950 was replaced with Constitution Number 19 the Year 1964 about the Basic Provisions of Judicial Power, which essentially gave the right to the citizen to get legal assistance in certain constraints. The stipulations are regulated in Article 26, Article 27, and Article 28 which stated that:

Article 26

"The right of each person who has a case to get legal assistance is regulated in the Constitution."

Article 27

Without prejudice of the interest of inspection, in a criminal case, a legal advisor from the arrestation and detention, someone is allowed to be contacted and provided legal assistance to him/her by not attending the initial investigation according to the provisions of law.

Article 28

"In assisting, a legal advisor must always be attempted in the purpose of justice, smoothened the settlement of cases by upholding Pancasila, Political Manifestos and its implementation guidelines as well as justice."

In its development during the new order era in 1970, Constitution Number 14 the Year 1970 about the Basic Provisions of Judicial Power was issued, which in essence also determined that citizens who had cases deserved to get legal assistance. This matter is stipulated in Article 35, Article 36, Article 37, and Article 38 which stated that:

Article 35

"Every person who is in the case has the right to get legal assistance."

Article 36

"In a criminal case, a suspect especially since the arrestation and/or detention has the right to contact and ask the help of a Legal Advisor."

Article 37

"In giving legal assistance, as in Article 36 above, Legal Advisor helps to smoothen case settlement by upholding Pancasila, law, and justice."

Article 38

"The aforementioned provisions in Articles 35, 36 and 37 were further arranged in Constitution."

Based on the arrangements, there are no clear regulations about advocate existence in Indonesia. The Constitution above only arranges the right of citizens to obtain legal assistance if they have a legal case in the court. However, the laws above do not explain who could provide legal assistance. So, the existence of advocates still has no strong position in the process of law and justice enforcement.

The arrangement of advocates was starting to get a clear point when the government finally formed Drafting Team for the Bill about Advocate Profession. The drafting team had finally completed their task in 
September 2000, by submitting the Bill to the leader of the House of Representatives. After passing through a long consideration, the Bill was finally legalized on 05 April 2003 as Constitution Number 18 the Year 2003 about Advocate.

As for the background of Advocate Bill, it can be seen from the government's view at the time of Advocate Profession Bill submission as delivered by Moh. Mahfud MD the Minister of Justice stated:

The birth of the Advocate Profession Bill which then became Advocate Law is based on three reasons of how important a separated Advocate Law is. First, the rules on advocate are still separated and most of them are out of date or do not suit with recent time. Secondly, the existing legislation did not specifically arrange the rights, obligations, authorities, and duties of legal aid providers. Third, the aspiration to create a sense of justice and legal security which requires order and peace, including from the legal service provider. ${ }^{1}$

The spirit from the birth of Constitution Number 18 the Year 2003 about Advocate (Advocate Law) is to create a constitutional state of law and fair law enforcement process, to make every person similar in front of the law, so they can get access to justice. It is seen in the preamble (considering) letter $a, b$, and c that explained:

a. The Republic of Indonesia, as a state law based on the Pancasila and Constitution Year 1945 of Republic Indonesia, aimed to create a prosperous, secure, peaceful, orderly, and fair system of nation's life;

b. That judicial power that is free from any interference and outside influence required advocate profession which is unconstrained, independent, and responsible, to hold an honest and fair judicature and have legal security for all justice seekers in enforcing the law, truth, justice, and human rights;

c. That Advocate as unconstrained, independent, and responsible profession in enforcing the law, should be secured and protected by Constitution for the sake of implementing the effort of legal supremacy enforcement;

Furthermore, in General Explanation of the first paragraph of Advocate Law, explains that: "the presence of advocate held an essential and strategic role to secure equality before the law as one of the main principals of state law." Likewise, in General Explanation of the second paragraph of Advocate Law, is clearly explained that: "In the effort of creating the principals of state law in social and state life, the role and function of Advocate as unconstrained, independent and responsible profession is essential, besides the judiciary and law enforcement agencies such as police and prosecutors." Moreover, the second paragraph explains that: "Through the given legal service, Advocate conducts his/her profession for the sake of justice according to law for the interest of the justice-seeking community, including the effort to empower society in realizing their fundamental rights before the law. Advocate as one of the elements of the judicial system is one of the pillars in enforcing law supremacy and human rights."

The third paragraph of General Explanation of Advocate Law explains the role of advocate outside the court, recently, has become more important and advanced in line with the development of societies' legal needs especially in entering the globalization era. Here is the complete explanation of the third paragraph of General Explanation:

Besides in the judicature process, the role of the Advocate is also seen in the professional line outside the Court. The need for an Advocate's legal service at this time is increasing, in line with the growth of societies' legal needs especially in entering the globalization era. By providing consulting services, negotiation as well as the making of trade contracts, the Advocate profession is also contributed to community empowerment and national law reformation, particularly in the fields of economics and trade, as well as in lawsuit settlement outside the court.

Based on the description of General Explanation above, it shows that advocate as a profession plays an important and strategic role, both through the roles in the judicial and outside the judiciary, which is through the provision of consulting services, negotiations, and in the making of trade contracts. In addition, the advocate profession also makes a significant contribution to community empowerment and national law reformation, especially in the economic and trade fields, including in the settlement of lawsuits out of court.

In this Reformation era, Indonesian societies wish for reliable advocates who will defend the rights of oppressed people. The advocate who has high integrity and morality, supported by a wide knowledge of the law, excellence in argumentation, has a logical and systematic way of thinking, as well as good rhetorical skill. Fiat Justicia et pereat mundus, the law must be enforced even if the sky falls. This motto is like the blood that flows in every advocate's soul. Advocate has noble and honorable duty to enforce law and justice on this earth. An advocate should be the pioneer of the enforcement of law supremacy and human rights in Indonesia as the mandate of the Constitution that the Republic of Indonesia is a state law.

\subsection{Political Law of Advocate Arrangements in Indonesia}

Based on the basic assumption that law is a political product that views law as a formalization or crystallization

${ }^{1}$ Treatise of Discussion Process of Advocate Profession Bill. Secretariat General of the Indonesian People's Representative Council, pg. 2829. 
of interacting and competing for political wills. ${ }^{1}$ Though the definition of legal politics itself still varies, some substantive similarities stated that legal politics is legal policy. The legal policy will be or has been implemented nationally by the government, which includes: first, legal development which has the core of making and updating legal materials to suit the needs. Second, the implementation of existing legal provisions, including affirmation of institutional functions and guidance for law enforcers. ${ }^{2}$ Thus, the understanding of political law includes the process of making and implementing laws that can indicate the nature and direction in which the law will be built and enforced. ${ }^{3}$

Stating Mahfud MD's statement that law is a political product, therefore politics intensively determined law. With more specific statements, the political configuration of a country will influence the characters of its law product. Several points of view are used by some academicians to see from its perspective and law study.

Bernard Arief Sidharta in analyzing the development of political law used the evolution model of three types of legal order in society which has politically organized in the form of state. ${ }^{4}$ The three types of legal order are Order of Repressive law, Order of Autonomous Law, and Order of Responsive Law. Order of Repressive law precedes the other two orders, it appears or is needed to settle various fundamental problems in establishing political order which is the prerequisite of law system and political system in achieving higher goals. Order of Autonomous Law presupposes and is built above the results achieved by Order of Repressive law. Order of Responsive Law rests on "constitutional cornerstones" the "Rule of Law" phase which is produced by Order of Autonomous Law. ${ }^{5}$

In contrast to Bernard Arief Sidharta, Mahfud MD stated that in a country with a democratic political configuration, the characters of its legal products are responsive/populistic, while in a country with an authoritarian political configuration, the characters of its legal products are orthodox/conservative/elitist. Changes in political configuration from authoritarian to democratic or vice versa have implications for the changes of legal product characters. ${ }^{6}$ Mahfud MD in his study focused on the nature or characteristics of legal products which are dichotomously distinguished between responsive/populistic law and orthodox/conservative/elitist law. ${ }^{7}$

From the two patterns of discussion on legal politics as explained before, in the study of political law of advocate arrangements in Indonesia, it is more likely to use the pattern explained by Mahfud MD based on the political configuration of a country. In a country with a democratic political configuration, the characters of its legal products are responsive/populistic, while in a country with an authoritarian political configuration, the characters of its legal products are orthodox/conservative/elitist. Changes in political configuration from authoritarian to democratic or vice versa, have implications for the changes of legal products characteristics. In his study, Mahfud MD focused on the characteristics of legal products which are dichotomously distinguished between responsive/populists law and orthodox/conservative/elitist law.

Considering political configuration in Indonesia before independence which the political configuration was authoritarian, the characters of legal products were orthodox/conservative/elitist. It is different from the postindependence period, especially in the post-reformation era which is more democratic, so the legal products including political law of advocate arrangements in Indonesia must be more responsive/populist to the needs of societies.

\section{Conclusion}

The development of law in a state could be seen from its political law. On the configuration of authoritarian politics, the characteristic of the legal product is orthodox. However, if the configuration of politics is democratic, so the legal product would be more responsive. So did with the law arrangements of Advocate, it would be aimed more at responsive character. Especially, the existence of Advocate Law is an effort to create state law principles in social and state life, the role and function of an advocate as a profession are expected to be able to bring about justice based on the law for the interest of the justice-seeking community, as well as an effort to empower society in realizing their fundamental rights before the law. A pillar in upholding law supremacy and human rights.

\section{Refference}

Yan Pramadya Puspa, (1977), Law Dictionary, Aneka, Semarang.

\footnotetext{
${ }^{1}$ Mahfud M.D., Political Law in Indonesia, LP3ES, Yogyakarta, 1998, pg.7

${ }^{2}$ Abdul Hakim Garuda Nasution, National Political Law. Paper for Practical Work of Legal Assistance, LBH, Surabaya, September, 1985, quoted from Moh. Mahfud MD, pg, 9.

${ }^{3}$ Moh. Mahfud MD, Op.cit., pg 9.

${ }^{4}$ Bernard Arief Sidharta, Reflection on Law Structure, A Study on Philosophical Foundation and Scientific Nature of Law as the Base of Indonesia Law Development., Mandar Maju, Bandung, 1999, pg. 50-52

${ }^{5}$ Philippe Nonet and Philip Selznik in the book "Law And Society Transition: Toward Responsive Law, 1978, pg. 14,15, as quoted from Bernard Arief Sidharta, ibid.

${ }^{6}$ Mahfud MD, Op.cit, pg 14-15

${ }^{7}$ Mahfud MD, Op.cit, page, 20
} 
K. Prent C.M., J. Adisubrata, \& W.J.S. Poerwadarminta, (1969), Latin-Indonesia Dictionary, Kanisius, Yogyakarta.

Henry Campbel Black, (1990), Black's Law Dictionary. St. Paul, MN: West Publishing Co.

Jhon Sinclair, Collins Cobuild,(1987) English Language Dictionary. William Collins Sons \& Co., Ltd., London.

Mardjono Reksodiputro, (2009)“ Indonesia Advocate Organization: Quo Vadis?”, JENTERA Law Journal, Edition 19, Year V.

Lasdin Wlas, (1989) The Horizon of Indonesia Advocate. Liberty. Yogjakarta.

Viswandro, Maria Matilda,\& Bayu Saputra,(2015), Knowing Law Enforcement Profession; Carier in Law Reference Book, Medpress Digital, Yogyakarta,

Sunarto, (2014), Active Role of Judges in Civil Suit. Prenadamedia. Jakarta.

Mahfud M.D., (1998) Political Law in Indonesia, LP3ES, Yogyakarta.

Abdul Hakim Garuda Nasution,(1985) National Political Law. Paper for Practical Work of Legal Assistance, LBH, Surabaya.

Bernard Arief Sidharta, (1999), Reflection on Law Structure, A Study on Philosophical Foundation and Scientific Nature of Law as the Base of Indonesia Law Development, Mandar Maju, Bandung. 